\title{
Capacity Estimation of Power Generation from MSW of Peshawar City
}

\author{
Salman Aatif, Muhammad Naeem Arbab, Ph.D. \\ Department of Electrical Engineering, \\ UET Peshawar, Pakistan
}

\begin{abstract}
Grim issue of Electricity shortages in most of developing countries leads to explore the potential in renewable and economical sources of energy. Power generation through Waste To Energy (WTE) Plants is an effective way to deal with the problems of MSW management and electricity shortages in densely populated cities of the world. In this paper, capacity estimation of Power generation from Municipal Solid Waste (MSW) of Peshawar city through Solid Waste Fueled Power Plant (SWFPP) is analyzed. For effective estimation of power generation through WTE plant, a detail study about estimation of Municipal Solid Waste of Peshawar city, composition and characteristics of collected waste, appropriate conversion technology; heat generated from it and ultimate power generation is discussed.
\end{abstract}

\section{Keywords}

Renewable Energy, Waste to Energy, Electricity, Power generation, Pakistan Power crisis, Municipal Solid Waste Fueled Power Plant.

\section{INTRODUCTION}

Life of every human being is highly dependent on energy, it is an indispensable necessity and plays crucial role for the achievements of basic needs such as water, food, shelter, education and health care. Energy consumption is a key indicator for identifying the degree of Social development of an area.

Rapid population growth in developing countries has accelerated the pace of urbanization which has resulted in many environmental problems including the significant problem of Municipal Solid Waste (MSW) management or treatment [1-4]. In 1999 European Union (EU) parliament approved an act which bounds every member country to stop disposal of MSW without proper treatment with effect from 2005 [5]. Several practices are used to make a usable work of MSW such as making compost [6], landfill gas to energy [3], power generation by incineration of waste and Plasma Gasification [7].

Power generation from MSW by Waste To Energy (WTE) power plants can be a good choice for countries like Pakistan which is the sixth populous country but facing major crises of its history in terms of power shortages, the problem is evident from Pakistan energy consumptions which is $0.037 \%$ of worlds total energy utilization with the population of $2.56 \%$ of world population [8]. The major reason of Pakistan's power crises includes demand and supply gaps, line losses, more dependency on oil based power plants and ultimately high cost of electricity. Total Power generation of country comprises $36 \%$ from imported oil, 32\% from hydro power plants, $27 \%$ from natural gas, and 5\% from nuclear and coal. One of the main cause of higher per unit price of electricity is substantial dependency on imported oil in power sector as in 2011 the country oil imports were $40 \%$ of total imports which took the trade deficit up to $12 \%[8,9]$. In such circumstances SWFPP solid waste fueled power plant which uses MSW a renewable resource as a fuel can be considered as an adequate resource in the energy mix of the country to bring down the average per unit cost of electricity.

The population and urbanization growth emanate the problems of MSW management and electricity shortages and both the problems can be minimized by converting municipal solid waste to electricity by the help of SWFPP.

For the effective estimation of the capacity of MSW fuelled Power Plant the precise estimation of MSW and heat generated is required as shown in functional block diagram of Figure 1.

Estimation of Municipal Solid Waste

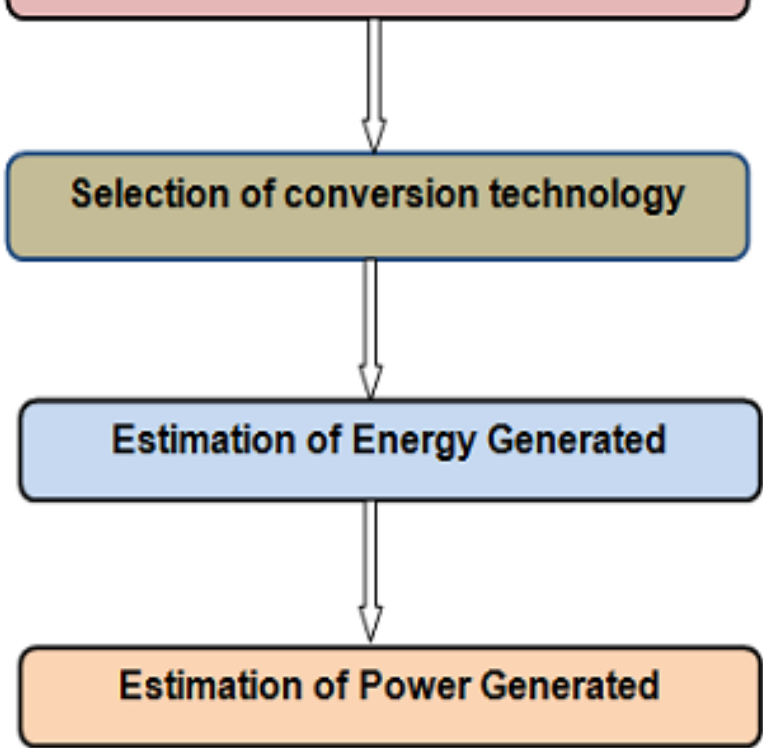

Fig 1: Block diagram of steps involved in estimation of power generation from MSW.

The following analysis has been done in this research document,

- The MSW per day of Peshawar city is estimated through the transportation capability and schedule of concern organizations.

- $5 \mathrm{~kg}$ samples of MSW have been collected from each of 12 different locations of the city for the analysis of composition of waste.

- $\quad$ Four different technologies of power generation has been discussed and one of them is proposed on the basis of economical and operational aspects. 
- The final calorific value has been calculated on the basis of composition of MSW of Peshawar city. The capacity of Power plant has been calculated as 12.4 MW on the basis of final calorific value.

- A suitable site has been proposed on the basis of certain constraints and is shown by the help of Google maps in Fig. 2.

\section{ESTIMATION OF MSW}

Peshawar is the capital city of Khyber Pukhtoonkhwa Province formally known as North West Frontier Province (NWFP) and lies between $33^{\circ} 44^{\prime}$ and $34^{\circ} 15^{\prime}$ north latitude and $71^{\circ} 22^{\prime}$ and $71^{\circ} 42^{\prime}$ east longitude. According to 1998 census the population of the city was approximately 2,019,118 with an annual growth rate of 3.5 percent. According to statics of provincial government currently the population of Peshawar is approximately 3.50 million as shown in Table 1.

Table 1. Area and population of Peshawar city

\begin{tabular}{|l|l|l|}
\hline Name of City & Area in Km2 & Population of City \\
\hline Peshawar & $1256 \mathrm{Km} 2$ & $(3.50$ million $)$ \\
\hline
\end{tabular}

The mentioned population does not include the count of afghan refugees and the count of population came from other areas for education, jobs etc and include only the registered citizens of city.

\subsection{MSW Collected Per Day}

Daily waste collection of the city is calculated by the analysis of transportation capability and schedule of Municipal
Corporation Peshawar (MCP) as shown in Table 2. Mainly three organizations involved in collection of MSW of city are MCP, Cantonment Board Peshawar (CBP) and Peshawar Development Authority (PDA).

Total amount of MSW estimated from Table 2 is 1331 ton, the waste generation rate can be calculated as,

Amount of MSW collected per day

Population of the concerned area

$=1331$ tons $/ 3.50$ million,

$=0.38 \mathrm{Kg}$ per person per day

Waste generation rate is less than that of Chennai India having $0.5-0.65 \mathrm{Kg} /$ person/day [3] and is slightly more than that of Chittagong Bangladesh [1]. One of the major parameters of waste generation rate is the extent of development of area. In developed areas the waste generation rate can reach as high as 2.75 to $4.0 \mathrm{Kg}$ per person per day [6]. Routing of MSW to storage points is a major element of municipal solid waste management in urban cities where only the collection systems of waste takes about 85 percent of overall expenses and disposal takes only $15 \%$ [10]. The organizations involved in the collection of MSW of city does not have much efficient systems of waste collection and management and actual figures of per capita MSW generation may be more than 0.38 $\mathrm{Kg}$ per person per day.

Table 2. MSW collection capability of Municipal Corporation Peshawar

\begin{tabular}{|c|l|c|c|c|c|}
\hline S. no & Type of Vehicle & Count & $\begin{array}{c}\text { MSW carrying ability } \\
\text { of each vehicle in tons }\end{array}$ & Trips per day & Total \\
\hline 1 & Containers & 131 & 5.0 & 3 & 655 tons \\
\hline 2 & Tractor trolley & 30 & 3.5 & 3 & 315 tons \\
\hline 3 & Pickup trucks & 28 & 1.0 & 3 & 90 tons \\
\hline 4 & $\begin{array}{l}\text { Mini Tractor } \\
\text { trolley }\end{array}$ & 15 & 2.0 & 2 & 184 tons \\
\hline 5 & Trucks & 23 & 4.0 & & 1331 tons \\
\hline
\end{tabular}

\subsection{Composition of Collected MSW}

MSW is mainly composite of food wastes (includes vegetables and fruits), paper products, wood, wood straws and wood materials (chips board, card boards), plastics and packing materials of different utility items, textile, rubber etc. Some of the waste materials can be recycled to make new goods but the majority of the remaining are in composite structure and cannot be reused or recycled. For the analysis of MSW of Peshawar a $5 \mathrm{Kg}$ sample of MSW is collected from twelve different areas of the city and data is tabulated in Table
3. Results shows a major share i.e. $31.9 \%$ of the MSW of Peshawar city consists of fruits and vegetable wastes. Second major share is of plastics which consist of $20.4 \%$ of total MSW. Paper products consists $13.1 \%$, wood straws and tree trimmings consists $12.3 \%$, textile consists $8.7 \%$ and leather and rubber consists $4.1 \%$ respectively. $9.1 \%$ of city MSW consists of non flammable materials which includes clay, debris etc. 
Table 3. Data of composition of MSW in different areas of Peshawar

\begin{tabular}{|c|c|c|c|c|c|c|c|c|c|}
\hline S. no & Date & Location & $\begin{array}{l}\text { Fruits \& } \\
\text { vegetables }\end{array}$ & Plastics & $\begin{array}{l}\text { Paper } \\
\text { products }\end{array}$ & $\begin{array}{l}\text { Wood, } \\
\text { Tree } \\
\text { Trimmings } \\
\text { and card } \\
\text { boards, }\end{array}$ & Textile & $\begin{array}{l}\text { Leather } \\
\& \\
\text { Rubber }\end{array}$ & $\begin{array}{l}\text { Clay, dabre } \\
\text { ceramics and } \\
\text { other non } \\
\text { flammable } \\
\text { materials }\end{array}$ \\
\hline 1 & $22 / 09 / 2014$ & $\begin{array}{l}\text { Qisa khwani } \\
\text { Bazar }\end{array}$ & 35 & 19 & 7 & 6 & 12 & 4 & 17 \\
\hline 2 & $22 / 09 / 2014$ & Gul Bahar & 33 & 27 & 12 & 11 & 5 & 5 & 7 \\
\hline 3 & $22 / 09 / 2014$ & $\begin{array}{l}\text { Chowk } \\
\text { Yadgar }\end{array}$ & 50 & 20 & 10 & 8 & 5 & 3 & 4 \\
\hline 4 & $22 / 09 / 2014$ & Akhon Abad & 26 & 20 & 8 & 20 & 8 & 4 & 14 \\
\hline 5 & $22 / 09 / 2014$ & Hayatabad & 28 & 21 & 13 & 13 & 9 & 4 & 12 \\
\hline 6 & $22 / 09 / 2014$ & $\begin{array}{l}\text { Govt college } \\
\text { Peshawar }\end{array}$ & 30 & 23 & 15 & 10 & 8 & 6 & 8 \\
\hline 7 & $22 / 09 / 2014$ & $\begin{array}{l}\text { Dabgari } \\
\text { Garden }\end{array}$ & 32 & 30 & 14 & 5 & 11 & 6 & 3 \\
\hline 8 & $22 / 09 / 2014$ & Old Tehsil & 35 & 21 & 13 & 3 & 7 & 3 & 12 \\
\hline 9 & 28/09/2014 & $\begin{array}{l}\text { University } \\
\text { Town }\end{array}$ & 23 & 17 & 18 & 19 & 8 & 3 & 11 \\
\hline 10 & 28/09/2014 & Board Bazar & 38 & 17 & 13 & 11 & 10 & 5 & 6 \\
\hline 11 & 28/09/2014 & $\begin{array}{l}\text { Peshawar } \\
\text { Cantt }\end{array}$ & 24 & 16 & 16 & 20 & 13 & 3 & 8 \\
\hline 12 & 28/09/2014 & $\begin{array}{l}\text { Peshawar } \\
\text { University }\end{array}$ & 29 & 14 & 18 & 21 & 8 & 3 & 7 \\
\hline & & $\begin{array}{l}\text { Composition } \\
\text { of MSW in } \\
\text { percentages }\end{array}$ & 31.9 & 20.4 & 13.1 & 12.3 & 8.7 & 4.1 & 9.0 \\
\hline
\end{tabular}

\section{WASTE TO ENERGY CONVERSION TECHNOLOGIES}

Different Waste to Energy (WTE) conversion technologies are in practice for power generation from MSW are as follows.

- Pyrolysis: The process in which the thermal decomposition of Municipal Solid Waste occur in the absence of air is called pyrolysis

- Conventional Gasification: In this process syngas is produced from Municipal Solid Waste in the presence of limited amount of air or oxygen

- Plasma Arc Gasification: In this process a hot ionized gas is produced by the decomposition of organic compounds by the help of plasma arc produced by plasma torches [11]
- Incineration: The process in which the MSW is burned in the presence of air or atmosphere, the process is also known as conventional Mass-Burn [12]

Amongst the four discussed technologies the pyrolysis and conventional gasification requires certain pylothetic reactions and are generally slow processes and are not desirable in case of Power generation from MSW. The plasma arc gasification has better efficiencies but is having high capital cost and plasma torches maintenance makes it more complex moreover the cost of per unit generated energy in case of Plasma gasification is around 10 cents per KWh where in case of mass-burn or incineration is around 5 cents per KWh [7]. Incineration or conventional mass-burn is less efficient in terms of power generation but is most simplest and convenient way of power generation from MSW. 


\section{ESTIMATION OF HEAT AND POWER GENERATION}

Each entity of Municipal Solid Waste is having a certain heating value in its dry form. Heating value of each entity is shown in Table 4 in $\mathrm{KJ} / \mathrm{Kg}$ and in Btu/lb $[2,13]$. On the basis of average heating values of each entity of MSW from Table 4, final calorific value of MSW is calculated in Table 5. MSW is having different moisture contents in its different constituents, area demography and weather conditions also have certain effects on moisture levels in constituents of waste. Average value of the moisture contents of each entity is considered from World Bank Technical Guidance Report and is given in Table 5 [2]. The percentage composition of MSW is taken from Table 3. After the deduction of moisture contents, the dry amount of MSW calculated in Table 5 is
$40.9 \%$ of total MSW collected. The final heating value of each constituents of Municipal Solid Waste in $\mathrm{KJ} / \mathrm{Kg}$ is calculated by the relation,

Average calorific value from Table $4 \times$ Dry MSW in $\%$ from Table 5

The final heating value of MSW is obtained as $9841.0 \mathrm{KJ} / \mathrm{Kg}$ by adding final calorific values of each constituents of waste from Table 5.

Table 4. Calorific values of different entities of MSW [2, 13]

\begin{tabular}{|c|c|c|c|c|c|}
\hline & & \multicolumn{2}{|c|}{ Calorific values of dry MSW constituents } & \multicolumn{2}{|c|}{ Selected average calorific values } \\
\hline S. no & Constituent & $\mathbf{k J} / \mathbf{k g}$ & $\mathbf{B t u} / \mathbf{l b}$ & $\mathbf{k J} / \mathbf{~ k g}$ & Btu / lb \\
\hline 1 & Plastics & $25,586-41,868$ & $11,000-18,000$ & $33,959.6$ & 14,600 \\
\hline 2 & Food waste & $18,608-20,934$ & $8000-9000$ & $19,538.4$ & 8400 \\
\hline 3 & Paper products & $16,282-18,608$ & $7000-8000$ & $17,677.6$ & 7600 \\
\hline 4 & Wood & $18,608-20,934$ & $8000-9000$ & $19,305.8$ & 8300 \\
\hline 5 & Leather, rubber & $23,260 \cdot 37,216$ & $10,000-16,000$ & $26,283.8$ & 11,300 \\
\hline 6 & Yard waste & $15,119-17,445$ & $6500-7500$ & $16,979.8$ & 7300 \\
\hline 7 & Textiles & 18,608 & 8000 & 18,608 & 8000 \\
\hline
\end{tabular}

Table 5. The final calorific value of Peshawar city waste

\begin{tabular}{|c|c|c|c|c|c|c|c|c|}
\hline & $\begin{array}{c}\text { Fruits \& } \\
\text { vegetables in } \\
\%\end{array}$ & $\begin{array}{c}\text { Plastics in } \\
\%\end{array}$ & $\begin{array}{c}\text { Paper } \\
\text { products in } \\
\%\end{array}$ & $\begin{array}{l}\text { Wood, Tree } \\
\text { Trimmings } \\
\text { and card } \\
\text { boards in \% }\end{array}$ & $\begin{array}{c}\text { Textile } \\
\text { products in } \\
\%\end{array}$ & $\begin{array}{c}\text { Rubber and } \\
\text { Leather in } \\
\%\end{array}$ & $\begin{array}{l}\text { Metals, } \\
\text { Clay, } \\
\text { and } \\
\text { nonflam } \\
\text { mable } \\
\text { substanc } \\
\text { es }\end{array}$ & Total \\
\hline $\begin{array}{c}\text { Composition } \\
\text { of each } \\
\text { entity of } \\
\text { MSW in } \%\end{array}$ & 31.9 & 20.4 & 13.1 & 12.3 & 8.7 & 4.1 & 9.0 & 100 \\
\hline $\begin{array}{c}\text { Moisture in } \\
\text { each entity } \\
\text { of MSW in } \\
\%\end{array}$ & 20.7 & 63.2 & 47.4 & 59.8 & 63 & 59.8 & 0 & --- \\
\hline $\begin{array}{c}\text { Dry MSW in } \\
\%\end{array}$ & 6.6 & 12.9 & 6.2 & 7.3 & 5.5 & 2.4 & 0 & $40.90 \%$ \\
\hline $\begin{array}{l}\text { Final heating } \\
\text { Value of } \\
\text { MSW }\end{array}$ & $1290.9 \mathrm{KJ} / \mathrm{Kg}$ & $\begin{array}{c}4381.9 \mathrm{KJ} / \\
\mathrm{Kg}\end{array}$ & $\begin{array}{c}1096.3 \mathrm{KJ} / \\
\mathrm{Kg}\end{array}$ & $\begin{array}{c}1414.2 \mathrm{KJ} / \\
\mathrm{Kg}\end{array}$ & $\begin{array}{c}1016 \mathrm{KJ} / \\
\mathrm{Kg}\end{array}$ & $\begin{array}{c}641.8 \mathrm{KJ} / \\
\mathrm{Kg}\end{array}$ & 0 & $\begin{array}{l}9841.0 \\
\mathrm{KJ} / \mathrm{Kg}\end{array}$ \\
\hline
\end{tabular}


Combustible portion of Municipal Solid Waste of Peshawar city is 40.90 percent from Table 5 and final heating value is calculated as $9841.0 \mathrm{KJ} / \mathrm{Kg}$.

The amount of combustible MSW in tons can be calculated as

$$
(40.9 \times 1331 \text { tons }) / 100
$$

$=544.370$ tons

Thermal systems used in WTE plants have the efficiencies of about $20 \%$ [1].

Considering the 544.370 tons of combustible MSW, 9841.0 $\mathrm{KJ} / \mathrm{Kg}$ of calorific value and $20 \%$ of thermal efficiency, The total energy generated per day can be calculated as,

$544370 \mathrm{Kg} /$ day $\times 9841.0 \mathrm{KJ} / \mathrm{Kg}{ }^{\times} 0.20=1071.44 \mathrm{GJ} /$ day

To calculate the capacity of power plant from 1071.44 GJ/day,

$1 \mathrm{MJ} /$ Second = $1 \mathrm{MW}$ of Power,

$1071.44 \mathrm{GJ}$

$$
=12.4 \mathrm{MW}
$$

$86400 \mathrm{sec}$

Hence the capacity of MSW fueled Power Plant for city of Peshawar is calculated as $12.4 \mathrm{MW}$.

\section{LOCATION OF POWER PLANT}

Selection of appropriate location for MSW fueled Power Plant is subject to certain constraints which includes the distance from city centre, accessibility from the city, distance from nearest power hub (grid station) etc. The proposed site for Power Plant is shown in Fig. 2 by the help of Google map and is about $13 \mathrm{Km}$ away from city centre, $07 \mathrm{Km}$ away from $1^{\text {st }}$ dumping point (Bahadar Kaley), and $06 \mathrm{Km}$ away from second dumping point (Shahid Abad). Proposed site is about $06 \mathrm{Km}$ from $500 \mathrm{KV}$ main Grid station which provides electricity to whole of city.

Real Genetic Algorithms is the most useful tool for selection of optimal path for MSW collection and supply to the proposed site efficiently and effectively[10].

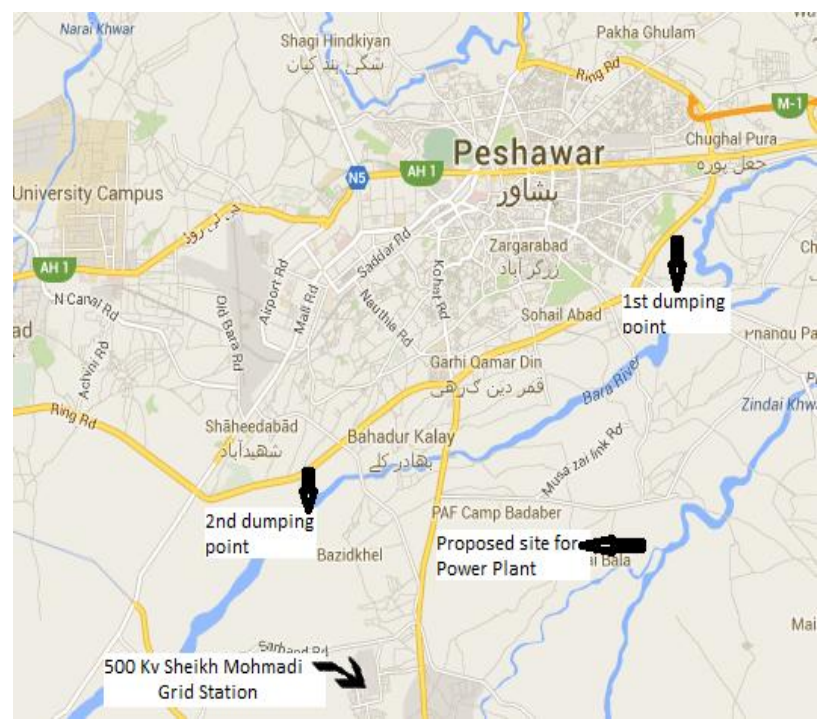

Fig 2: Google Map of Peshawar City presenting both of the existing dumping points, $500 \mathrm{KV}$ grid station and proposed site for power plant.

\section{CONCLUSIONS}

Capacity Estimation in this document is calculated on the basis of MSW collection Capabilities of Municipal Corporation Peshawar. The capacity can be improved by improving the waste collection system of concern organizations.

The main factors of Electricity shortages and power crisis in Pakistan are demand and supply gap and high cost of per unit of electricity due to greater dependency on imported oil based power plants. This research can utilize to build SWFPP to minimize the demand and supply gap. Similar estimation can be worked out for other major cities of the country like Karachi, Lahore etc having populations twice trice of Peshawar.

The current national average per unit cost of electricity of Pakistan is 14 cents per KWh [14], where the per unit cost from incineration based SWFPP is around 5 cents per KWh [reference] which is quite less as compare to national average and hence can be utilized to reduce the national average cost of electricity.

SWFPP projects have positive Social Return on Investment (SROI) and are 'Triple $\mathrm{P}$ ' projects which have profitable status and have positive impact on people and planet [15]. Installation of SWFPP with appropriate emission systems will be helpful in decreasing pollution level of urban cities as majority of uncollected or discarded MSW is burned through un professional ways in open air causing unpleasant effects on the overall environment of the city.

\section{REFERENCES}

[1] P. S. Khan and M. Hoque, "Installation of a Solid-Waste fuelled Power Plant in Chittagong, Bangladesh: A feasibility study," in Strategic Technology (IFOST), 2010 International Forum on, 2010, pp. 208-212.

[2] World Bank, "Municipal Solid Waste Incineration," 1999.

[3] C. Palanichamy, N. S. Babu, and C. Nadarajan, "Municipal solid waste fueled power generation for India," Energy Conversion, IEEE Transactions on, vol. 17, pp. 556-563, 2002.

[4] S. T. MRUS and C. A. PRENDERGAST, "Heating value of refuse derived fuel," in Proceedings of... National Waste Processing Conference, 1978, p. 365.

[5] S. Bardi and A. Astolfi, "Modeling and Control of a Waste-to-Energy Plant [Applications of Control]," Control Systems, IEEE, vol. 30, pp. 27-37, 2010.

[6] Z. Z. Noor, R. O. Yusuf, A. H. Abba, M. A. Abu Hassan, and M. F. Mohd Din, "An overview for energy recovery from municipal solid wastes (MSW) in Malaysia scenario," Renewable and Sustainable Energy Reviews, vol. 20, pp. 378-384, 2013.

[7] R. R. Baidoo, F. Yeboah, and H. Singh, "Energy and economic analysis of closed-loop plasma waste-to-power generation model and in comparison with Incineration and Micro-Turbine Models," in Electrical Power \& Energy Conference (EPEC), 2009 IEEE, 2009, pp. 1-7.

[8] S. Z. Farooqui, "Prospects of renewables penetration in the energy mix of Pakistan," Renewable and Sustainable Energy Reviews, vol. 29, pp. 693-700, 2014. 
[9] I. N. Kessides, "Chaos in power: Pakistan's electricity crisis," Energy Policy, vol. 55, pp. 271-285, 2013.

[10] I. von Poser and A. Awad, "Optimal routing for solid waste collection in cities by using real genetic algorithm," in Information and Communication Technologies, 2006. ICTTA'06. 2nd, 2006, pp. 221-226.

[11] Los Angeles County Solid Waste Management Committee, "Conversion Technology Evaluation Report," 2005.

[12] G. C. Young, Municipal Solid Waste to Energy Conversion Processes: Economic, Technical, and Renewable Comparisons: Wiley, 2010.
[13] Q. Yufei, B. Yan, S. Zhongli, and Z. Keming, "Design of Combustion Control System for MSW Incineration Plant," in Intelligent Computation Technology and Automation (ICICTA), 2008 International Conference on, 2008, pp. 341-344.

[14] National Electric Power Regulatory Authority (NEPRA). (06/11/2014). Tariff. Available: http://www.nepra.org.pk/tariff.htm

[15] C. Cheung, K. Bengtson, M. Moser, A. Wu, B. Parrilla, and C. Mastrangelo, "Development of a renewable hybrid power generation system," in Systems and Information Engineering Design Symposium, 2009. SIEDS'09., 2009, pp. 55-60. 